\title{
Onvoldoende uitleg bij toepassing van het 'comply or explain'- principe in Europa
}

\section{Een vergelijking tussen Nederland, België, Duitsland, Italië en het VK}

\section{Annika Galle}

SAMENVATTING In dit artikel worden de mate en kwaliteit van de toepassing van het 'comply or explain'-principe voor beursgenoteerde ondernemingen in Nederland, België, Duitsland, Italië en het Verenigd Koninkrijk onderzocht. Dit is de eerste studie naar de toepassing van het principe waarin simultaan meerdere landen voor opeenvolgende jaren met één en dezelfde meetmethode worden onderzocht. De resultaten laten zien dat ondernemingsgrootte en de tijd van positieve invloed zijn op de mate en kwaliteit van naleving. Op de vraag of het 'comply or explain'-principe juridisch ingebed dient te worden in de wet of in beursregels kan aan de hand van dit onderzoek geen eenduidig antwoord worden gegeven en dit dient verder te worden onderzocht in samenhang met de culturele kenmerken en het rechtsstelsel van een land. Hoewel de mate van codenaleving hoog is, laat de kwaliteit van de uitleg bij niet-naleving van codebepalingen te wensen over. Verdere finetuning van het 'comply or explain'-principe is derhalve nodig voor een effectieve en juiste toepassing van het principe.

RELEVANTIE VOOR DE PRAKTIJK Het reeds bestaande onderzoek naar het 'comply or explain'-principe gaat voornamelijk over de mate van naleving van nationale corporate governance codes: het aantal afwijkingen wordt geteld. De kwaliteit van de uitleg bij niet-nageleefde codebepalingen en de verklarende factoren hiervoor worden vaak onderbelicht, terwijl dit juist de kernpunten van het huidige Europese debat zijn. In deze studie is dit voor 237 jaarverslagen over de jaren 2005-2007 voor vijf landen onderzocht waardoor de uitkomsten een feitelijke bijdrage kunnen leveren aan het lopende debat en aan verbetering van de toepassing van het 'comply or explain'-principe in de praktijk.

\section{Inleiding}

Het 'comply or explain'-principe (het 'pas toe of leg uit'principe) is tegenwoordig mede door de Richtlijn 2006/46/EC en het Groenboek "Het EU-kader inzake corporate governance 2011" een centraal element in de Europese corporate governance. Consensus over de reikwijdte en de noodzakelijke voorwaarden voor een effectief functioneren van dit principe is echter nog niet bereikt. In het Groenboek "Het EU-kader inzake corporate governance" wordt onder andere gesteld dat de uitleg bij afwijkingen van codebepalingen onbevredigend is. In dit artikel wordt op basis van een empirisch onderzoek naar de kwaliteit van de uitleg bij afwijkingen met codebepalingen in Nederland, België, Duitsland, Italië en het Verenigd Koninkrijk (het VK) bezien hoe het daadwerkelijk met die onbevredigende uitleg is gesteld en wat mogelijke verklarende factoren zijn. Tot op heden ontbrak een dergelijke studie met een onderzoeksperiode van meer dan één jaar (2005-2007) op basis van één meetmethode en dataset voor verschillende landen tegelijk. Daarbij is in de wetenschappelijke literatuur het 'comply or explain'-principe nog niet of nauwelijks vanuit de economische theorie (legitimiteitstheorie en theorie op marktfalen) toegelicht. Alvorens tot het empirische deel van dit artikel over te gaan, benadert paragraaf 2 het 'comply or explain'-principe dan ook vanuit deze invalshoek. Vervolgens wordt in paragraaf 3 ingegaan op de juridische inbedding van het 'comply or explain'-principe, waarna paragraaf 4 het eerdere onderzoek naar codenaleving en het 'comply or explain'-principe kort aanstipt. Paragraaf 5 behandelt de onderzoeksmethode en gebruikte dataset, alvorens in paragraaf 6 opeenvolgend de beschrijvende statistiek, correlatieanalyses en regressieanalyses worden gepresenteerd. Paragraaf 7 tot slot, vat het onderzochte samen en presenteert de conclusies. 


\section{Het 'comply or explain'-principe in de theorie}

Het 'comply or explain'-principe is theoretisch gezien vanuit de agentschapstheorie (Jensen en Meckling, 1976) een variatie op de economische remedie disclosure. Om de agency-problemen tussen de agenten en principalen te minimaliseren is men tot een aantal zogenaamde oplossingsrichtingen (remedies) gekomen. Het geven van opening van zaken (disclosure) is een dergelijke oplossingsrichting en hiermee wordt getracht informatieasymmetrie en opportunistisch gedrag te verminderen (Santen, 2007). Middels het 'comply or explain'-principe wordt geopenbaard hoe een onderneming haar corporate-governancebeleid vormgeeft en hoe de toepasselijke corporate governance code al dan niet wordt nageleefd. Naast de agentschapstheorie zijn ook de legitimiteitstheorie en de theorie op marktfalen van invloed op het 'comply or explain'-principe. In de bestaande literatuur omtrent het 'comply or explain'-principe worden deze twee theorieën in relatie tot het principe niet verder uiteengezet, derhalve een korte toelichting.

\section{Legitimiteitstheorie}

De legitimiteitstheorie legt uit waarom ondernemingen informatie willen en/of moeten openbaar maken. Maurer (1971) definieert legitimering als het proces waarin een organisatie (in casu een onderneming) haar bestaansrecht moet rechtvaardigen ten opzichte van de omgeving waarin het functioneert. Door middel van dit organisatorisch gedrag, bestaande uit het zoeken naar en verkrijgen van legitimiteit vanuit de samenleving, vergroten ondernemingen hun overlevingskans (DiMaggio en Powell, 1983; Hooghiemstra et al., 2008). Tegenwoordig kan een onderneming het zich niet veroorloven om de samenleving te negeren; de continuiteit is afhankelijk van de perceptie in de maatschappij over de reputatie. Een onderneming moet haar bestaan en activiteiten - onder andere door middel van transparantie - voortdurend aan de stakeholders en de samenleving als geheel rechtvaardigen (Boot en Soeting, 2004). Daarbij wordt met name het jaarverslag gezien als een geschikt instrument om informatie te 'disclosen' doordat aan dit document geloofwaardigheid wordt toegekend en het niet wordt geassocieerd met reclame-uitingen (Neu et al., 1998). De ontwikkeling van corporate-governancegerelateerde regelgeving ten aanzien van verplichte en vrijwillige openbaarmaking van informatie (waaronder het 'comply or explain'-principe) kan deels worden verklaard door deze legitimiteitstheorie. Direct na de boekhoudschandalen gebruikten ondernemingen onder meer het 'comply or explain'-principe om het vertrouwen van de aandeelhouders te herwinnen, onregelmatigheden op tijd te traceren, daarmee schandalen te voorkomen, en om de corporate-governancestructuur van de onderneming te legitimeren. Tegenwoor- dig gelden nog steeds dezelfde argumenten voor openbaarmaking van informatie door middel van het 'comply or explain'-principe. Ondernemingen willen de markt informeren dat zij een goed of beter corporate-governancebeleid hebben dan anderen en hopen daarmee extra investeerders te trekken.

\section{Theorie op marktfalen}

Naast legitimatie van het bestaan en van het corporategovernancebeleid, is ook marktfalen reden voor transparantie middels het 'comply or explain'-principe. Marktfalen omvat de situatie waarin - op welke markt dan ook - de hoeveelheid of kwaliteit van het product zoals gevraagd door de consument niet hetzelfde is als de kwantiteit en/of kwaliteit zoals geleverd door leveranciers. Het zogenaamde sociale optimum wordt bij marktfalen niet bereikt door een bepaald gebrek in de economische ideaalfactoren (Leftwich, 1980). Informatieasymmetrie is een dergelijk gebrek; perfecte financiële markten, waarin agenten en principalen alle benodigde informatie ontvangen en waarin moral hazard en adverse selectie niet voorkomen, bestaan niet. Niettemin tracht men zo dicht mogelijk bij een perfecte financiële markt te komen door deze problemen te minimaliseren door onder andere verplichte of vrijwillige openbaarmaking van informatie (Schön, 2006). Een investeerder zal enkel investeren wanneer de informatieasymmetrie tussen hem en het management (de agenten) tot een bevredigend niveau is gebracht en de naleving van regulering op het gebied van openbaarmaking van informatie (waaronder het 'comply or explain'-principe) draagt hieraan bij. Het 'comply or explain'-principe is vanuit de agentschapstheorie een variatie op de economische remedie disclosure en is beinvloed door de legitimiteitstheorie en de theorie van het marktfalen: door legitimering van het corporategovernancebeleid aan stakeholders proberen ondernemingen marktfalen te voorkomen, vertrouwen te winnen en extra investeerders te trekken.

\section{Juridische inbedding van het 'comply or explain'-principe}

Ten behoeve van de duiding van de resultaten uit het empirisch onderzoek zoals verder uiteengezet in paragraaf 6, wordt hier ingegaan op de juridische inbedding van het 'comply or explain'-principe in de vijf onderzochte landen.

In Europa is betoogd dat hetgeen als 'goede' corporate governance wordt beschouwd voortdurend aan verandering onderhevig is en voor ondernemingen geldt 'one size does not fit all'. De onderscheiden regelgevers in Europa ontwierpen dan ook een juridisch raamwerk dat alleen minimumbepalingen oplegt en de ondernemingen voldoende flexibiliteit geeft in de manier van naleving: soft law werd ontwikkeld in de vorm van nationa- 
le corporate governance codes met het 'comply or explain'-principe. In 2006 werd deze aanpak bevestigd door Richtlijn 2006/46/EG. Hierdoor werd beursgenoteerde ondernemingen EU-breed opgelegd een corporate-governanceverklaring in het jaarverslag op te nemen met een verwijzing naar de corporate governance code waar de onderneming aan onderworpen is, evenals op welke punten de onderneming ervan afwijkt en om welke redenen. De EU-lidstaten hebben Richtlijn 2006/46/EC op verschillende wijzen geïmplementeerd wat eveneens tot uiting komt in hun toepassing (zie paragraaf 6). Een onderscheid kan worden gemaakt tussen vijf gedefinieerde corporate-governancerechtsarrangementen afgeleid van Wymeersch (2005) en Voogsgeerd (2006); zie tabel 1.

Voor het VK geldt corporate-governancerechtsarrangement $\mathrm{B}$, waar de juridische inbedding van de code en het 'comply or explain'-principe is vastgelegd in de listing rules; code en 'comply or explain'-principe worden ondersteund door niet-wettelijke normen. Voor Nederland en tegenwoordig ook voor België en Italië geldt corporate-governancerechtsarrangement $\mathrm{C}$ waar de code en het 'comply or explain'-principe worden gefaciliteerd door wettelijke regels (een verankering in de wet). Voor Duitsland geldt arrangement D (metaregulering): hoewel de code een basis heeft in de wetgeving, wordt de code niet van groot belang geacht en de gedetailleerde nationale vennootschapswetgeving des te meer (regulering van zelfregulering). In rechtsarrangement D speelt de wetgeving niet meer enkel een ondersteunende rol en de zelfregulering wordt of is gereguleerd (Voogsgeerd, 2006). Voor Duitsland betekent dit dat bepalingen uit de corporate governance code eveneens in de wet zijn opgenomen. In de onderstaande paragrafen aangaande het empirisch onderzoek wordt de invloed van de wijze van de juridische inbedding op de mate en kwaliteit van codenaleving verder onderzocht. In eerste instantie wordt verwacht dat hoe strikter het 'comply or explain'-principe in een land is vastgelegd, hoe beter de codenaleving en kwaliteit van de uitleg bij afwijkingen is. Daarentegen zullen ook zaken als de ervaring met het 'comply or explain'-principe in een specifiek land en de cultuur ten opzichte van zelfregulering meespelen.

\section{Eerder onderzoek naar codenaleving en het 'comply or explain'-principe}

Tot op heden is weinig onderzoek naar de toepassing van het 'comply or explain'-principe verricht, staat het zelfs in de kinderschoenen en is het telkens gericht op één land (met uitzondering van de studie van de RiskMetrics Group ${ }^{1}$ uit 2009) met vaak jaarlijks wisselende onderzoeksmethoden. De meeste bestaande studies hebben diffuse uitkomsten en focussen op de relatie tussen codenaleving en ondernemingspresta- ties. Deze paragraaf vermeldt kort de belangrijkste uitkomsten van studies die de codenaleving wel diepgaander onderzoeken. Studies die de codenaleving en de kwaliteit van de uitleg bij niet-naleving verder analyseren laten weliswaar een stijging in naleving gedurende de onderzochte jaren zien, maar de kwaliteit van de uitleg bij niet-naleving is slecht (bij 51\% van de afwijkingen was de uitleg te standaard en niet voldoende informatief) (Arcot en Bruno, 2006). Daarnaast onderscheiden Von Werder, Talaulicar en Kolat (2005) bepaalde zogenaamde neuralgische codebepalingen: problematische codebepalingen waarvan wordt verwacht dat ze nauwelijks worden nageleefd in de toekomst, zoals codebepalingen betreffende persoonlijke aansprakelijkheid, bestuurdersbezoldiging en de samenstelling van de raad van commissarissen. Voorts concluderen Von Werder, Talaulicar en Kolat (2005) dat de codenaleving positief gerelateerd lijkt te zijn met de ondernemingsgrootte. Hooghiemstra et al. (2008) betwijfelen in hun studie de effectiviteit van het 'comply or explain'-principe aangezien de gegeven uitleg bij de codeafwijkingen relatief standaard is en weinig ondernemingsspecifieke kenmerken vermeldt; zij stellen dat een 'one size fits all'-benadering zichtbaar is wat niet in lijn is met de bedoeling van het 'comply or explain'-principe.

De tot nu toe enige internationale studie naar codenaleving is de "Study on Monitoring and Enforcement Practices in Corporate Governance in the Member States” van de RiskMetrics Group van september 2009.

\section{Tabel 1 Corporate-governancerechtsarrangementen}

\begin{tabular}{|c|c|c|c|}
\hline $\begin{array}{l}\text { Serie } \\
\text { nummer }\end{array}$ & Naam & Kenmerken & Land \\
\hline$A$ & Zuivere zelfregulering & $\begin{array}{l}\text { - Weinig gedetailleerde vennoot- } \\
\text { - } \text { schapswetgeving } \\
\text { - Code overlap tussen code en wet } \\
\text { - Colternatief voor wetgeving }\end{array}$ & België tot 2010 \\
\hline B & $\begin{array}{l}\text { Ondersteuning door } \\
\text { niet-wettelijke } \\
\text { normen }\end{array}$ & $\begin{array}{l}\text { - Materiële normen in codes nader } \\
\text { ondersteund door regelgeving (bijv. } \\
\text { beursregels) } \\
\text { - } \\
\text { Resultaat: compliance met normen } \\
\text { niet geheel vrijwillig meer (ver- } \\
\text { sterkte zelfregulering) }\end{array}$ & $\begin{array}{l}\text { VK en Italië tot } \\
2005\end{array}$ \\
\hline C & $\begin{array}{l}\text { Facilitering door } \\
\text { wettelijke regels }\end{array}$ & $\begin{array}{l}\text { - Zoals B, maar code wordt gefacili- } \\
\text { teerd door of heeft wettelijke basis } \\
\text { in wetgeving }\end{array}$ & $\begin{array}{l}\text { Nederland, Italië } \\
\text { sinds } 2006 \text { en } \\
\text { België sinds } 2010\end{array}$ \\
\hline D & $\begin{array}{l}\text { Regulering van } \\
\text { zelfregulering } \\
\text { (metaregulering) }\end{array}$ & $\begin{array}{l}\text { - Bijv. als gevolg van niet-naleving } \\
\text { heeft wetgeving meer dan een on- } \\
\text { dersteunende of faciliterende rol }\end{array}$ & Duitsland \\
\hline$E$ & Zuivere regulering & $\begin{array}{l}\text { - Codes hebben geen rol van } \\
\text { betekenis } \\
\text { - Accent op gedetailleerde nationale } \\
\text { wetgeving }\end{array}$ & \\
\hline
\end{tabular}


Zij onderzoeken de codenaleving van 270 beursgenoteerde ondernemingen voor 18 EU-lidstaten voor het jaar 2008 (15 ondernemingen per land). Alhoewel geen ontwikkelingen door de jaren heen kunnen worden weergegeven, toont deze studie enkele interessante resultaten. Van de onderzochte ondernemingen geeft $86 \%$ op enigerlei wijze informatie over codenaleving middels het 'comply or explain'-principe en 23\% geeft aan te voldoen aan alle toepasselijke codebepalingen. Een gemiddelde van drie uitgelegde codebepalingen per onderneming was zichtbaar en vaak gericht op bepalingen omtrent de raad van bestuur en het beloningsbeleid. Het gemiddelde aantal afwijkingen was hoger voor mid-caps dan voor large-caps. De RiskMetrics Group concludeert dat het 'comply or explain'principe brede acceptatie geniet, maar de kwaliteit van de uitleg is van een onbevredigend niveau en moet worden verbeterd door het versterken van het 'comply or explain'-principe zelf en door een grotere rol van de marktbrede toezichthouders en de accountants (RiskMetrics Group, 2009). Derhalve laten bovenstaande kort samengevatte resultaten zien dat verder onderzoek nodig is om tot aanbevelingen te komen voor de benodigde verbeteringen in de praktijk. Zoals ook de Europese Commissie in haar Groenboek aangeeft, dient de kwaliteit van de uitleg te worden verbeterd evenals het toezicht op de codenaleving.

\section{Methode en onderzoekspopulatie}

In deze paragraaf wordt de samenstelling van de dataset uiteengezet, evenals de onderzoeksmethode en betreffende variabelen, waarna de onderzoeksresultaten verder worden gevisualiseerd.

\section{Dataset}

In totaal zijn 237 jaarverslagen over de jaren 20052007 voor de vijf onderzochte landen gereviewed (België, Duitsland, Italië, Nederland en het VK) middels zogenaamde inhoudsanalyse. ${ }^{2,3}$ De corporate-governanceverklaringen zijn op de toepassing van het 'comply or explain'-principe onderzocht en meer specifiek

\section{Tabel 2 Overzicht onderzoekspopulatie}

\begin{tabular}{|l|c|c|c|c|c|c|}
\hline Aantal ondernemingen per land \\
\hline Compartiment marktkapitalisatic & VK & BEL & DLD & IT & NL & Totaal \\
\hline A & 25 & 23 & 35 & 25 & 27 & 135 \\
\hline B & 15 & 17 & 15 & 15 & 10 & 72 \\
\hline C & 10 & 10 & 0 & 10 & 0 & 30 \\
\hline Totaal & 50 & 50 & 50 & 50 & 37 & 237 \\
\hline
\end{tabular}

Categorie $A$ betreft ondernemingen met een marktkapitalisatie van meer dan 1 biljoen euro. Categorie $B$ betreft ondernemingen met een marktkapitalisatie tussen de 150 miljoen en 1 biljoen euro.

Categorie $\mathrm{C}$ betreft ondernemingen met een marktkapitalisatie van lager dan 150 miljoen euro. ook op de kwaliteit van de uitleg. Om een onderdeel van de dataset te vormen, moesten de desbetreffende ondernemingen over de jaren 2005-2007 aan dezelfde beursindex ${ }^{4}$ genoteerd zijn en binnen dezelfde categorie marktkapitalisatie vallen. Hierbij is telkens uitgegaan van 50 ondernemingen per land en voor Nederland betrof dit 37 ondernemingen aangezien er niet meer beursondernemingen waren met een gelijkblijvende marktkapitalisatie over de onderzochte jaren. Gekozen is voor de onderzoeksjaren 2005-2007 omdat voor alle onderzochte landen toen het 'comply or explain'-principe reeds gold en destijds de EURichtlijn werd aangenomen. Van verouderde data is geen sprake aangezien dit tot dusver de enige dataset is die op één wijze voor meerdere jaren voor meerdere landen de toepassing van het 'comply or explain'principe in Europa meet. Daarbij laten latere studies die telkens een enkel land betreffen vergelijkbare resultaten zien, alhoewel daarmee dus geen landenvergelijkingen kunnen worden gemaakt. Tabel 2 geeft een overzicht van de onderzoekspopulatie.

De beperkingen van dit onderzoek worden vooral gevormd door de corporate-governanceverklaringen zelf. De mate en kwaliteit van codenaleving door de ondernemingen is gemeten aan de hand van de inhoud van de corporate-governanceverklaringen. Ondernemingen kunnen hierin echter aangeven dat zij de toepasselijke codebepalingen naleven, maar in de praktijk hiervan afwijken. Materiële codenaleving is echter zeer moeilijk te meten en dit probleem is ook inherent aan het gekozen corporate-governancemodel. Echter, het gaat in dit onderzoek vooral ook over de trends, relaties en de kwaliteit van de uitleg bij niet-naleving en niet enkel om de harde nalevingscijfers. Zoals Durisin en Puzone (2009, p. 279) stellen aangaande corporategovernanceonderzoek: "There is an empirical gap in crossnational studies in the literature".

\section{Variabelen}

In paragraaf 6 zijn de belangrijkste resultaten van de uitgevoerde analyses weergegeven. Een aantal variabelen heeft hierbij enige toelichting nodig. Allereerst de afhankelijke variabelen zelf, de mate van naleving van de betreffende corporate governance codes en daarmee samenhangende ook de kwaliteit van uitleg. De mate en kwaliteit van naleving van de toepasselijke corporate governance codes worden uit de corporate-governanceverklaringen afgeleid. Daarbij wordt afgegaan op wat de onderneming zelf aangeeft ten aanzien van de codenaleving. Geeft een onderneming aan van een codebepaling af te wijken, dan wordt dit ook gemeten als een afwijking. Deze variabele wordt in deze studie dan ook CodenalevingI genoemd. Wanneer ook de kwaliteit van de uitleg bij afgeweken codebepalingen wordt meegewogen, dan is gerekend met de afhankelijke variabe- 
le CodenalevingII. In de kwaliteit van de gegeven uitleg bij codeafwijkingen is een aantal categorieën te onderscheiden zoals zichtbaar in tabel 3. Deze categorieën zijn afgeleid uit eerder onderzoek (Arcot en Bruno, 2007; Galle, 2012). De categorieën met volgnummer 1, 2 en 3 worden als onvoldoende uitleg beschouwd en de volgnummers 4, 5 en 6 als een voldoende uitleg; en daarmee als correcte toepassing van het 'comply or explain'-principe ('made-to-measure'-codenaleving). Variabele CodenalevingII omvat dan ook het gemeten aantal codebepalingen inclusief de niet-nageleefde codebepalingen met een voldoende uitleg (volgnummers 4,5 , en 6 ).

Het is te verwachten dat ondernemingen tijd nodig hebben om de regels uit de toepasselijke corporate governance code toe te passen en om te wennen aan het 'comply or explain'-principe waardoor de mate van naleving en de kwaliteit van toepassing gedurende de jaren zal stijgen. Eerder onderzoek toont diffuse uitkomsten, stellende dat tijd niet of juist wel van invloed is, met daarbij soms ook in de tijd een zeker verzadigingspunt in de mate van naleving (Shabbir, 2008; Weir en Laing, 2000; Arcot en Bruno, 2006). Het aantal jaar dat het 'comply or explain'-principe van toepassing is in een land (variërend van 1 tot 15 jaar) is dan ook als de variabele tijd in de analyses meegenomen. Daarbij is eveneens interessant om te bezien of de juridische inbedding zoals in paragraaf 3 verder uiteengezet nog van invloed is op de mate van naleving en de toepassing van het principe, waarbij in eerste instantie wordt verwacht dat hoe strikter het 'comply or explain'-principe in een land is vastgelegd, hoe beter de codenaleving en kwaliteit van de uitleg bij afwijkingen is. Tot slot is de ondernemingsgrootte (weergegeven in categorieën van marktkapitalisatie en de drie belangrijkste beursindices in een land) een belangrijke variabele. Als gevolg van relatief lagere nalevingskosten en grotere zichtbaarheid wordt verwacht dat grotere ondernemingen beter scoren dan kleinere, wat reeds in verschillende studies is bevestigd (Talaulicar \& Von Werder, 2008; Hooghiemstra, Van Ees \& Van der Laan, 2008).

\section{Resultaten}

\subsection{Beschrijvende statistiek}

Tabel 4 laat per land en per jaar het nalevingspercentage zien bestaande uit de toegepaste codebepalingen (CodenalevingI). Codenaleving kan worden uitgedrukt in percentages van het aantal bepalingen of als het aantal afwijkingen. Het aantal afwijkingen zelf geeft weinig informatie aangezien het aantal codebepalingen per land erg verschilt (van 36 voor Italië tot 128 voor Nederland). Opvallend is dat per onderneming gemiddeld 2,5 codebepalingen niet worden nageleefd. De percentages zijn op zich hoog, maar hoe het 'comply or explain'-principe daadwerkelijk wordt gebruikt is hierin niet meegenomen. Wellicht wordt bij een afwijking geen uitleg gegeven of een slechts zeer algemene uitleg.

Tabel 5 geeft hierin een beter beeld door ook de kwaliteit van de uitleg mee te nemen (CodenalevingII). Tabel 5 laat per land en per jaar het nalevingspercentage zien bestaande uit de toegepaste codebepalingen samen met de uitgelegde codebepalingen met een vol-

\section{Tabel 3 Categorieën kwaliteit van uitleg}

\begin{tabular}{|c|l|}
\hline Volgnummer & Categorie kwaliteit van uitleg bij afwijking codebepaling \\
\hline $\mathbf{1}$ & Geen uitleg: De onderneming geeft geen uitleg voor de afwijking. \\
\hline $\mathbf{2}$ & $\begin{array}{l}\text { Algemeen: Een algemene of niet-specifieke (m.b.t. de onderneming) uitleg is } \\
\text { gegeven. Vaak zijn standaardzinnen gebruikt zonder enige specifieke details. } \\
\text { Bijvoorbeeld dat de niet-naleving in het belang van de onderneming is, dat het } \\
\text { de gangbare praktijk is of enkel dat het als noodzakelijk wordt gezien. }\end{array}$ \\
\hline $\mathbf{3}$ & $\begin{array}{l}\text { In lijn: Een uitleg met een algemeen karakter wordt gegeven waarbij zinnen } \\
\text { uit de niet-nageleefde codebepaling worden herhaald. }\end{array}$ \\
\hline $\mathbf{4}$ & $\begin{array}{l}\text { Beperkt: Een uitleg wordt gegeven welke meer uitleg geeft dan Algemeen of } \\
\text { In lijn, maar nog steeds nalaat specifiek te zijn opgesteld naar het karakter of } \\
\text { de omstandigheden van de onderneming. }\end{array}$ \\
\hline $\mathbf{5}$ & $\begin{array}{l}\text { Overgang: Een uitleg welke wijst op een overgangssituatie waardoor de on- } \\
\text { derneming tijdelijk niet naleeft. }\end{array}$ \\
\hline $\mathbf{6}$ & $\begin{array}{l}\text { Authentiek: Een uitleg wordt gegeven die als authentiek beoordeeld wordt in } \\
\text { de geest van de toepasselijke code. Dergelijke uitleg is specifiek gericht op de } \\
\text { onderneming, gemotiveerd, in detail en verifieerbaar. }\end{array}$ \\
\hline
\end{tabular}

Tabel 4 Nalevingspercentages (toegepaste bepalingen - Codenalevingl)

\begin{tabular}{|l|c|c|c|c|c|}
\hline \multicolumn{1}{|c|}{ Land } & $\begin{array}{c}\text { Percentages codenaleving } \\
\mathbf{2 0 0 5}\end{array}$ & $\begin{array}{c}\text { Percentages codenaleving } \\
\mathbf{2 0 0 6}\end{array}$ & $\begin{array}{c}\text { Percentages codenaleving } \\
\mathbf{2 0 0 7}\end{array}$ & $\begin{array}{c}\text { Percentages codenaleving } \\
\text { 2005-2007 }\end{array}$ & $\begin{array}{c}\text { Gemiddeld aantal afwij- } \\
\text { kingen per onderneming }\end{array}$ \\
\hline BEL & 96,53 & 96,60 & 96,50 & 96,54 & 3,01 \\
\hline DLD & 92,70 & 94,00 & 94,29 & 93,67 & 2,55 \\
\hline IT & 95,83 & 97,65 & 98,11 & 97,48 & 1,56 \\
\hline NL & 94,99 & 95,35 & 95,17 & 95,17 & 5,46 \\
\hline VK & 96,75 & 97,33 & 97,63 & 97,24 & 1,33 \\
\hline Gemiddelde & 95,50 & 96,32 & 96,43 & 96,11 & \\
\hline
\end{tabular}


Tabel 5 Nalevingspercentages (toegepaste bepalingen en voldoende uitgelegde bepalingen - Codenalevingll)

\begin{tabular}{|l|c|c|c|c|c|}
\hline \multicolumn{1}{|c|}{ Land } & $\begin{array}{c}\text { Percentage codenaleving } \\
\mathbf{2 0 0 5}\end{array}$ & $\begin{array}{c}\text { Percentage codenaleving } \\
\mathbf{2 0 0 6}\end{array}$ & $\begin{array}{c}\text { Percentage codenaleving } \\
\mathbf{2 0 0 7}\end{array}$ & $\begin{array}{c}\text { Percentage codenaleving } \\
\text { 2005-2007 }\end{array}$ & $\begin{array}{c}\text { Gemiddeld aantal onvol- } \\
\text { doende uitgelegde bepa- } \\
\text { lingen per onderneming } \\
\text { 2005-2007 }\end{array}$ \\
\hline BEL & 98,26 & 98,41 & 98,08 & 98,25 & 1,52 \\
\hline DLD & 95,90 & 96,50 & 96,83 & 96,41 & 1,45 \\
\hline IT & 97,61 & 98,69 & 99,15 & 98,67 & 0,83 \\
\hline NL & 99,19 & 99,37 & 98,79 & 99,12 & 1,00 \\
\hline VK & 98,71 & 99,00 & 99,00 & 98,90 & 0,53 \\
\hline Gemiddelde & 98,18 & 98,56 & 98,48 & 98,42 & 1,02 \\
\hline
\end{tabular}

Tabel 6 Categorieën in kwaliteit van de uitgelegde bepalingen weergegeven in percentages

\begin{tabular}{|c|c|c|c|c|c|c|c|c|}
\hline \multirow[t]{2}{*}{ Land } & \multicolumn{3}{|c|}{$\begin{array}{c}\text { Percentage per } \\
\text { niveau }\end{array}$} & \multirow{2}{*}{$\begin{array}{l}\text { Subtotaal } \\
\text { onvol- } \\
\text { doende } \\
\text { uitgelegd }\end{array}$} & \multirow[t]{2}{*}{ Beperkt } & \multirow[t]{2}{*}{$\begin{array}{l}\text { Over- } \\
\text { gang }\end{array}$} & \multirow[t]{2}{*}{$\begin{array}{l}\text { Authen- } \\
\text { tiek }\end{array}$} & \multirow{2}{*}{$\begin{array}{l}\text { Subtotaal } \\
\text { voldoen- } \\
\text { de uitge- } \\
\text { legd }\end{array}$} \\
\hline & $\begin{array}{l}\text { Geen } \\
\text { uitleg }\end{array}$ & $\begin{array}{l}\text { Alge- } \\
\text { meen }\end{array}$ & In lijn & & & & & \\
\hline BEL & 18,62 & 29,08 & 2,55 & 50,26 & 27,55 & 6,38 & 15,82 & 49,74 \\
\hline DLD & 23,58 & 17,01 & 16,72 & 57,31 & 21,19 & 6,27 & 15,22 & 42,69 \\
\hline IT & 14,21 & 36,04 & 0,00 & 50,25 & 38,07 & 2,54 & 9,14 & 49,75 \\
\hline NL & 7,79 & 7,79 & 3,34 & 18,92 & 48,42 & 13,54 & 19,11 & 81,08 \\
\hline VK & 13,44 & 25,27 & 0,54 & 39,25 & 32,26 & 23,66 & 4,84 & 60,75 \\
\hline $\begin{array}{l}\text { Gemid- } \\
\text { delde }\end{array}$ & 14,98 & 20,07 & 5,15 & 40,21 & 34,87 & 10,19 & 14,74 & 59,79 \\
\hline
\end{tabular}

\section{Tabel 7 Pearson correlaties tussen Codenalevingl en Codenalevingll en de tijd}

\begin{tabular}{|l|r|r|r|}
\hline & Codenalevingl & Codenalevingll & \multicolumn{1}{c|}{ Tijd } \\
\hline Codenalevingl & 1 & & \\
\hline Codenalevingll &, $590^{(*)}$ & 1 & \\
\hline Tijd &,$- 226(*)$ &,$- 156(*)$ & 1 \\
\hline
\end{tabular}

${ }^{* *} .=p<0,01 ;{ }^{*} .=p<0,05 ; n=711$

Pearson correlaties zijn toegepast aangezien het ratiovariabelen betreft

(Van Dalen, 2002)

Codenalevingl Aantal gemeten codeafwijkingen

Codenalevingll Aantal gemeten codeafwijkingen met een kwalitatief slechte uitleg (categorie 1, 2 en 3)

Tijd Aantal jaren dat het principe van toepassing is (variërend van 1 tot 15 jaar)

doende uitleg (aldus de hoogste drie niveaus, zijnde (4) een meer dan enkel een algemene uitleg maar nog niet geheel ondernemingsspecifiek, (5) een uitleg die aangeeft dat de afwijking tijdelijk is of (6) een specifiek gedetailleerde verifieerbare uitleg). Ook is het (gemid- deld) aantal niet-toegepaste codebepalingen met een onvoldoende uitleg weergegeven in de tabel.

Met name de laatste paar ontbrekende procenten tot aan de honderd procent zijn hier van belang: in deze gevallen is het 'comply or explain'-principe onjuist gebruikt. Tabel 6 geeft per land de zes gemeten categorieën in de kwaliteit van de uitleg van de niet-nageleefde codebepalingen aan in percentages.

Een afdoende uitleg voor de niet-nageleefde bepalingen ontbreekt vaak: in totaal heeft 40,2 procent van de nietnageleefde bepalingen een onvoldoende uitleg. Per onderneming worden gemiddeld 2,5 codebepalingen niet nageleefd, waarvan gemiddeld één bepaling onvoldoende wordt uitgelegd. In deze studie wordt geen 100\%-naleving van de codebepalingen beargumenteerd, maar als niet-nageleefde bepalingen worden uitgelegd dient de gegeven uitleg wel voldoende te zijn.

\subsection{Correlatieanalyses}

\section{Variabele tijd}

In deze studie wordt zoals hierboven reeds aangegeven verwacht dat de mate en kwaliteit van naleving positief wordt beïnvloed door de tijd dat het 'comply or explain'-principe van toepassing is in een land. Ondernemingen hebben tijd nodig om de regels uit de toepasselijke corporate governance code toe te passen en om te wennen aan het 'comply or explain'-principe waardoor de mate van naleving en de kwaliteit van toepassing gedurende de jaren zal stijgen. Tabel 7 toont deze relatie dan ook aan met een negatieve significante correlatie; hoe langer het 'comply or explain'-principe van toepassing is, hoe lager het aantal codeafwijkingen (met een onvoldoende uitleg bij CodenalevingII).

\section{Variabele juridische inbedding}

In tabel 1 zijn reeds de vijf mogelijke manieren van juridische inbedding van het 'comply or explain'-principe uiteengezet (zuivere zelfregulering, ondersteuning 
door niet-wettelijke normen, facilitering door wettelijke regels, metaregulering en zuivere regulering). Verwacht wordt dat hoe strikter het 'comply or explain'principe juridisch verankerd is in een land, hoe beter de codenaleving en kwaliteit van de uitleg bij afwijkingen is. Voor de regulering van de zelfregulering (metaregulering) zijn dan ook de beste scores te verwachten ten opzichte van de andere manieren van juridische inbedding. Aangezien de variabele juridische inbedding een nominale variabele is, werd een ANOVA-test gedaan, waarvan de significantieresultaten zijn samengevat in tabel 8 (Van Dalen en De Leede, 2002). ${ }^{5}$

De bovenstaande resultaten geven telkens een verschil in de mate van codenaleving aan tussen twee verschillende soorten juridische inbedding; de manier van inbedding is aldus van enige invloed op de codenaleving. Zowel voor CodenalevingI als CodenalevingII (waarbij de kwaliteit van de uitleg is meegenomen) scoort ondersteuning door niet-wettelijke normen het beste: ofwel de laagste gemiddelden $(1,37$ en 0,61$)$ en daarmee de minste codeafwijkingen. Vervolgens scoren metaregulering voor CodenalevingI en facilitering door wettelijke regels voor CodenalevingII het beste; zij hebben aldus de minste codeafwijkingen. In eerste instantie zou men verwachten dat hoe strikter het 'comply or explain'principe in een land is ingebed, hoe hoger de mate van naleving en/of kwaliteit van de uitleg is, aangezien een sterke inbedding vertrouwen in en consensus over het principe toont wat wellicht resulteert in meer naleving. Daarom zou men verwachten dat metaregulering en facilitering door wettelijke regels de hoogste nalevingspercentages scoren. Echter, blijkbaar is ondersteuning door niet-wettelijke normen afdoende (bijvoorbeeld door listing rules). Waarschijnlijk is dit wat te gemakkelijk gesteld en daarom worden bij de multivariate analyses ook de andere variabelen meegenomen. Mede van belang zijn variabelen zoals de tijd dat het principe van toepassing is. Voor het VK bijvoorbeeld geldt ondersteuning door niet-wettelijke normen, maar ook reeds een lange toepassingsperiode van het principe.

\section{Variabele ondernemingsgrootte}

In deze studie wordt zoals hierboven aangegeven verwacht dat de mate en kwaliteit van naleving positief wordt beïnvloed door de grootte van de ondernemingen. Als gevolg van relatief lagere nalevingskosten en grotere zichtbaarheid wordt verwacht dat grotere ondernemingen beter scoren dan kleinere, wat in verschillende studies is bevestigd. Ondernemingsgrootte wordt gezien als een algemeen erkende voorspeller voor codenaleving (Dedman, 2000; Pollock et al., 2002).

Uit de tabellen 9a en 9b blijkt dat ten aanzien van het marktkapitalisatiecompartiment in samenhang met CodenalevingI (het aantal door de onderneming aangege-

\section{Tabel 8 Analyses (ANOVA-test) tussen Codenaleving/ en Codenalevingll en de juridische inbedding}

\begin{tabular}{|c|c|c|c|c|}
\hline & $\begin{array}{l}\text { Juridische } \\
\text { inbedding I }\end{array}$ & $\begin{array}{l}\text { Juridische } \\
\text { inbedding II }\end{array}$ & $\begin{array}{c}\text { Verschil } \\
\text { tussen I en II }\end{array}$ & $\begin{array}{l}\text { Conclusie } \\
\text { resultaten }\end{array}$ \\
\hline \multirow[t]{5}{*}{$\begin{array}{l}\text { Code- } \\
\text { naleving } \\
\text { I }\end{array}$} & $\begin{array}{l}\text { Zuivere zelfre- } \\
\text { gulering (gemid- } \\
\text { delde } 2,6467 \text { ) }\end{array}$ & $\begin{array}{l}\text { Ondersteuning } \\
\text { door niet-wet- } \\
\text { telijke normen } \\
\text { (gemiddelde } \\
\text { 1,37 = laagste) }\end{array}$ & $1,27667\left(^{\star}\right)$ & $\begin{array}{l}\text { Zuivere zelfregulering sig- } \\
\text { nificant lagere naleving dan } \\
\text { ondersteuning door niet- } \\
\text { wettelijke normen }\end{array}$ \\
\hline & $\begin{array}{l}\text { Zuivere zelfre- } \\
\text { gulering (gemid- } \\
\text { delde } 2,6467 \text { ) }\end{array}$ & $\begin{array}{l}\text { Facilitering door } \\
\text { wettelijke regels } \\
\text { (gemiddelde } \\
3,4692 \text { = laag- } \\
\text { ste) }\end{array}$ &,$- 82253\left({ }^{\star}\right)$ & $\begin{array}{l}\text { Facilitering door wettelijke } \\
\text { regels significant lagere } \\
\text { naleving dan door zuivere } \\
\text { zelfregulering }\end{array}$ \\
\hline & $\begin{array}{l}\text { Ondersteuning } \\
\text { door niet-wet- } \\
\text { telijke normen } \\
\text { (gemiddelde } \\
1,37 \text { = laagste) }\end{array}$ & $\begin{array}{l}\text { Facilitering door } \\
\text { wettelijke regels } \\
\text { (gemiddelde } \\
3,4692 \text { = laag- } \\
\text { ste) }\end{array}$ & $-2,09919\left(^{*}\right)$ & $\begin{array}{l}\text { Facilitering door wettelijke } \\
\text { regels significant lagere } \\
\text { naleving dan ondersteu- } \\
\text { ning door niet-wettelijke } \\
\text { normen }\end{array}$ \\
\hline & $\begin{array}{l}\text { Ondersteuning } \\
\text { door niet-wet- } \\
\text { telijke normen } \\
\text { (gemiddelde } \\
1,37 \text { = laagste) }\end{array}$ & $\begin{array}{l}\text { Metaregulering } \\
\text { (gemiddelde } \\
2,5533 \text { ) }\end{array}$ & $-1,18333\left({ }^{\star}\right)$ & $\begin{array}{l}\text { Metaregulering significant } \\
\text { lagere naleving dan onder- } \\
\text { steuning door niet-wettelij- } \\
\text { ke normen }\end{array}$ \\
\hline & $\begin{array}{l}\text { Facilitering door } \\
\text { wettelijke regels } \\
\text { (gemiddelde } \\
3,4692 \text { = hoog- } \\
\text { ste) }\end{array}$ & $\begin{array}{l}\text { Metaregulering } \\
\text { (gemiddelde } \\
2,5533 \text { ) }\end{array}$ &, $91586\left(^{*}\right)$ & $\begin{array}{l}\text { Facilitering door wettelijke } \\
\text { regels significant lagere } \\
\text { naleving dan door metare- } \\
\text { gulering }\end{array}$ \\
\hline \multirow[t]{4}{*}{$\begin{array}{l}\text { Code- } \\
\text { naleving } \\
\text { II }\end{array}$} & $\begin{array}{l}\text { Zuivere zelfre- } \\
\text { gulering (gemid- } \\
\text { delde } 1,34 \text { ) }\end{array}$ & $\begin{array}{l}\text { Ondersteuning } \\
\text { door niet-wet- } \\
\text { telijke normen } \\
\text { (gemiddelde } \\
0,61 \text { = laagste) }\end{array}$ &, $73000\left(^{*}\right)$ & $\begin{array}{l}\text { Zuivere zelfregulering sig- } \\
\text { nificant lagere naleving dan } \\
\text { door ondersteuning door } \\
\text { niet-wettelijke normen }\end{array}$ \\
\hline & $\begin{array}{l}\text { Zuivere zelfre- } \\
\text { gulering (gemid- } \\
\text { delde } 1,34 \text { ) }\end{array}$ & $\begin{array}{l}\text { Facilitering door } \\
\text { wettelijke regels } \\
(0,8815)\end{array}$ & ,45848(*) & $\begin{array}{l}\text { Zuivere zelfregulering sig- } \\
\text { nificant lagere naleving dan } \\
\text { facilitering door wettelijke } \\
\text { regels }\end{array}$ \\
\hline & $\begin{array}{l}\text { Ondersteuning } \\
\text { door niet-wet- } \\
\text { telijke normen } \\
\text { (gemiddelde } \\
0,61 \text { = laagste) }\end{array}$ & $\begin{array}{l}\text { Metaregulering } \\
\text { (gemiddelde } \\
1,4467=\text { hoog- } \\
\text { ste) }\end{array}$ &,$- 83667\left(^{\star}\right)$ & $\begin{array}{l}\text { Metaregulering significant } \\
\text { lagere naleving dan onder- } \\
\text { steuning door niet-wettelij- } \\
\text { ke normen }\end{array}$ \\
\hline & $\begin{array}{l}\text { Facilitering door } \\
\text { wettelijke regels } \\
\text { (gemiddelde } \\
0,8815 \text { ) }\end{array}$ & $\begin{array}{l}\text { Metaregulering } \\
\text { (gemiddelde } \\
1,4467=\text { hoog- } \\
\text { ste) }\end{array}$ &,$- 56515\left(^{\star}\right)$ & $\begin{array}{l}\text { Metaregulering siginificant } \\
\text { lagere naleving dan facilite- } \\
\text { ring door wettelijke regels }\end{array}$ \\
\hline $\begin{array}{l}\text { *. Het vers } \\
\text { Codenale } \\
\text { Codenale }\end{array}$ & $\begin{array}{l}\text { hil in de gemiddeld } \\
\text { igl } \\
\text { ngll }\end{array}$ & $\begin{array}{l}\text { en }=<, 05 \\
\text { gemeten codeafwi } \\
\text { gemeten codeafwi } \\
\text { orie } 1,2 \text { en } 3 \text { ) }\end{array}$ & $\begin{array}{l}\text { Igen } \\
\text { Igen met ee }\end{array}$ & kwalitatief slechte uitleg \\
\hline
\end{tabular}

ven codeafwijkingen) geen significante relatie zichtbaar is. Wordt de kwaliteit van de gegeven uitleg bij niet-naleving meegewogen, dan is wel een significante positieve relatie zichtbaar; hoe kleiner de onderneming (hoe lager de marktkapitalisatie), hoe groter het aantal afwijkingen met een slechte uitleg. Behalve marktkapitalisa- 
Tabel 9a en 9b Spearman correlaties tussen Codenalevingl en Codenalevingll en de ondernemingsgrootte

\begin{tabular}{|l|r|r|r|}
\hline & $\begin{array}{c}\text { Codenaleving } \\
\text { I }\end{array}$ & $\begin{array}{c}\text { Codenaleving } \\
\text { II }\end{array}$ & $\begin{array}{c}\text { Comparti- } \\
\text { ment }\end{array}$ \\
\hline Codenalevingl & 1 & & \\
\hline Codenalevingll &, $653\left(^{(*)}\right.$ & 1 & \\
\hline Compartiment & 0,024 &, $114\left(^{* *}\right)$ & \\
\hline $\begin{array}{l}* * \\
\text { Spearman correlaties zijn toegepast aangezien het ordinale en } \\
\text { ratiovariabelen betreft (Van Dalen, 2002) (Field, 2005). } \\
\text { Codenalevingl } \\
\text { Codenalevingll }\end{array}$ & $\begin{array}{l}\text { Aantal gemeten codeafwijkingen } \\
\text { Aantal gemeten codeafwijkingen met een } \\
\text { kwalitatief slechte uitleg (categorie 1,2 en 3) }\end{array}$ \\
Compartiment & $\begin{array}{l}\text { Het marktkapitalisatiecompartiment waar de } \\
\text { onderneming in valt (large caps (A), midcaps (B) } \\
\text { en small caps (C)) }\end{array}$ \\
\hline
\end{tabular}

tie is de beursindex ook een veel gebruikte variabele. Aangezien per land de indices en de toelatingscriteria verschillen, is de belangrijkste index van een land als 1 gecodeerd, de één na belangrijkste als 2 en de twee na belangrijkste als 3 . Zowel voor CodenalevingI als CodenalevingII wordt een positieve relatie waargenomen, daarmee implicerend dat hoe kleiner de onderneming (hoe hoger de code voor de beursindex), hoe meer afwijkingen met codebepalingen. Als daarbij ook de kwaliteit van de uitleg in ogenschouw wordt genomen, dan is die relatie zelfs nog sterker.

\subsection{Multivariate analyses}

Hier worden de resultaten van de regressieanalyses beschreven voor de variabelen CodenalevingI en CodenalevingII (nu uitgedrukt in percentages) met de tijd dat het 'comply or explain'-principe geldt in een land (variërend van 1 tot 15 jaar), de juridische inbedding en de ondernemingsgrootte (uitgedrukt in categorie marktkapitalisatie en de drie belangrijkste indices). ${ }^{6}$ Tabel 10 toont de resultaten van de regressieanalyse. ${ }^{7}$

Voor beide modellen laat de verklarende variabele tijd een positief significante correlatie $(p<0,01)$ met de mate en kwaliteit van naleving zien, daarmee een hogere naleving voorspellende hoe langer het 'comply or explain'principe in een land geldt $(0,227 \%$ voor CodenalevingI en $0,136 \%$ voor CodenalevingII). Ten aanzien van de dummy's aangaande de juridische inbedding zijn beide modellen significant $(p<0,01)$. In model CodenalevingI laten de ondernemingen met als juridische inbedding zuivere zelfregulering de beste nalevingscores zien $(4,130)$. Voor model CodenalevingII heeft de juridische inbedding 'gefaciliteerd door wettelijke regels' de hoogste bètawaarde $(2,830)$. Ofwel wanneer de kwaliteit van de uitleg van de niet-nageleefde bepalingen wordt meegenomen, dan scoort de striktere juridische inbedding 'gefaciliteerd door wettelijke regels' het beste en wan-

\begin{tabular}{|c|c|c|c|}
\hline & $\begin{array}{c}\text { Codenaleving } \\
\text { I }\end{array}$ & $\begin{array}{c}\text { Codenaleving } \\
\text { II }\end{array}$ & Indextype \\
\hline Codenalevingl & 1 & & \\
\hline Codenalevingll &, $\left.6533^{* *}\right)$ & 1 & \\
\hline Compartiment &, $101^{(*)}$ &, $\left.093^{(* \star}\right)$ & 1 \\
\hline \multicolumn{4}{|c|}{$\begin{array}{ll}*{ }^{*} .=p<0,01 ;{ }^{*}=p<0,05 ; n=711 \\
\text { Spearman correlaties zijn toegepast aangezien het ordinale en } \\
\text { ratiovariabelen betreft (Van Dalen, 2002) (Field, 2005). } \\
\text { Codenalevingl } & \text { Aantal gemeten codeafwijkingen } \\
\text { Codenalevingll } & \text { Aantal gemeten codeafwijkingen met een } \\
& \text { kwalitatief slechte uitleg (categorie 1,2 en 3) } \\
& \text { Het indextype waar de onderneming aan genoteerd } \\
& \text { is (telkens de drie belangrijkste indices van een } \\
& \text { land, bijv. AEX, AMX en AMS) }\end{array}$} \\
\hline
\end{tabular}

neer de kwaliteit van de uitleg niet wordt meegenomen, dan voorspelt de juridische inbedding 'zuivere zelfregulering' de hoogste mate van codenaleving. De variabelen ten aanzien van de marktkapitalisatie laten vrijwel geen significantie zien; ofwel ondernemingsgrootte is niet relevant in het model. Echter de dummy's aangaande de beursindices laten anders zien. Zowel voor model CodenalevingI als voor CodenalevingII is te voorspellen dat hoe belangrijker de index waar de onderneming aan genoteerd is (in de praktijk hoe groter de onderneming), hoe hoger de voorspelde stijging in de mate en kwaliteit van naleving is.

\section{Samenvatting en conclusies}

Uit recente studie blijkt dat de uitleg bij afwijkingen van codebepalingen vaak onbevredigend is. Veelal wordt een niet-ondernemingsspecifieke en uniforme uitleg gegeven bij niet-naleving van een bepaling van de nationale corporate governance code. Om te komen tot verbetering in de toepassing in de praktijk wordt hier vanuit de EU aandacht voor gevraagd. In de tweede paragraaf is beschreven dat het 'comply or explain'principe is beïnvloed door de legitimiteitstheorie en de theorie op het marktfalen. Ondernemingen willen middels het gebruik van het 'comply or explain'-principe in hun corporate-governanceverklaring in het jaarverslag hun corporate-governancestructuur legitimeren en trachten daarbij de informatieasymmetrie te minimaliseren waardoor zij hopelijk investeerders aantrekken. In paragraaf 3 is aangegeven dat het 'comply or explain'-principe en de nationale corporate governance codes op verschillende wijzen in het nationale juridische stelsel kunnen worden ingebed. Tegenwoordig vindt het 'comply or explain'-principe een basis in de wetgeving of beursregels; welke van de twee is afhankelijk van zaken als de ervaring met het 'comply or explain'-principe in een land, en de cultuur ten opzichte van zelfregulering. Paragraaf 4 beschrijft kort eerder 
verricht onderzoek naar het 'comply or explain'-principe. In dit artikel worden 237 jaarverslagen over de jaren 2005-2007 voor de landen Nederland, België, Duitsland, Italië en het VK onderzocht.

In het onderzoek is de mate en de kwaliteit van de naleving onderzocht. Bij de mate van naleving is afgegaan op wat de onderneming zelf aangeeft; geeft de onderneming aan van de toepasselijke code af te wijken, dan wordt dit gemeten als een afwijking. Wanneer vervolgens ook de kwaliteit van de uitleg bij de afwijkingen wordt meegenomen, dan is een onderscheid in zes kwaliteitsniveaus gemaakt waarbij de hoogste drie niveaus als voldoende uitleg en daarmee als correcte toepassing van het 'comply or explain'principe worden gezien. Uit de beschrijvende statistiek volgt dat de mate van naleving in de gemeten periode op zich hoog is (van $92,70 \%$ tot $98,11 \%$ ) en dat per onderneming gemiddeld 2,5 codebepalingen niet wordt nageleefd. Wordt echter ook de kwaliteit van de uitleg meegenomen dan volgt dat een aanzienlijk deel van de niet-nageleefde codebepalingen $(40,2 \%)$ onvoldoende wordt uitgelegd. In deze studie wordt vanuit de gedachte 'one size does not fit all' geen $100 \%$ naleving beargumenteerd, maar als niet-nageleefde codebepalingen worden uitgelegd dan dient de gegeven uitleg wel voldoende te zijn. Uit de correlatieanalyses volgt dat de tijd dat het principe van toepassing is in een land de mate en kwaliteit van naleving positief beïnvloedt. Hetzelfde geldt voor ondernemingsgrootte; hoe groter de onderneming hoe beter de mate en kwaliteit van naleving. Wat betreft de juridische inbedding van het 'comply or explain'-principe in een land, lijkt vastlegging in beursregels het meest afdoende alhoewel hierbij zaken als het rechtsstelsel en culturele kenmerken niet zijn meegenomen en wel van belang zijn. Uit de regressieanalyses kunnen wat betreft de variabelen tijd en ondernemingsgrootte dezelfde conclusies worden getrokken. Ten aanzien van de meest geschikte juridische inbedding voor het 'comply or explain'principe kan geen eenduidig antwoord worden gegeven op basis van het uitgevoerde onderzoek. Hiervoor is vervolgonderzoek benodigd dat ook zaken als cultuurverschillen meeneemt en de wijze waarop het toezicht op de codenaleving is vorm gegeven. Dit laatste is volgens de EU eveneens een verder punt voor on-
Tabel 10 Resultaten regressieanalyse

\begin{tabular}{|c|c|c|}
\hline Variabele & Model Codenalevingl & Model Codenalevingll \\
\hline \multirow[t]{2}{*}{ Constant } & 91,541 & 94,773 \\
\hline & $146,9413^{\star \star}$ & $215,805^{\star *}$ \\
\hline \multirow[t]{2}{*}{ Tijd } & 0,227 & 0,136 \\
\hline & $4,432^{\star *}$ & $3,759^{\star *}$ \\
\hline \multirow[t]{2}{*}{ Zuivere zelfregulering (dummy) } & 4,130 & 2,689 \\
\hline & $8,835^{\star *}$ & $8,162^{\star *}$ \\
\hline \multirow{2}{*}{$\begin{array}{l}\text { Ondersteuning door niet-wettelijke } \\
\text { normen (dummy) }\end{array}$} & 1,981 & 1,552 \\
\hline & $3,857^{\star \star}$ & $4,289^{\star \star}$ \\
\hline \multirow{2}{*}{$\begin{array}{l}\text { Facilitering door wettelijke regels } \\
\text { (dummy) }\end{array}$} & 2,978 & 2,830 \\
\hline & $7,2286^{\star \star}$ & $9,746^{\star *}$ \\
\hline \multirow[t]{2}{*}{ Large caps (dummy) } & $-1,263$ & 0,412 \\
\hline & $(2,1769)^{*}$ & 1,008 \\
\hline \multirow[t]{2}{*}{ Midcaps (dummy) } & $-0,725$ & 0,024 \\
\hline & $-1,507$ & 0,071 \\
\hline \multirow[t]{2}{*}{ Belangrijkste index (dummy) } & 2,770 & 0,854 \\
\hline & $4,676^{* *}$ & $2,046^{*}$ \\
\hline \multirow[t]{2}{*}{ Eén na belangrijkste index (dummy) } & 2,442 & 0,803 \\
\hline & $5,367^{\star \star}$ & $2,503^{*}$ \\
\hline$\sigma^{2}$ & 13,900 & 6,907 \\
\hline $\mathbf{R}^{2}$ & 0,156 & 0,157 \\
\hline Adjusted R2 & 0,147 & 0,148 \\
\hline F-waarde & $16,257^{\star \star}$ & $16,368^{\star *}$ \\
\hline \multicolumn{3}{|l|}{${ }^{* \star} .=p<0,01 ;{ }^{*} .=p<0,05 ; n=711$} \\
\hline
\end{tabular}

derzoek omdat een effectief functioneren van het 'comply or explain'-principe aldus nog niet is bereikt. De recent opgestelde richtlijnen van de monitoring commissies in Nederland en in het VK over wat een juiste uitleg is bij niet-naleving van codebepalingen zijn een stap vooruit (Monitoring Commissie, 2012), maar verdere finetuning - ook vanuit de EU - blijft derhalve nodig om in de praktijk de juiste toepassing van het principe te bereiken.

Mr. dr. J.G.C.M. Galle is als universitair docent financiee recht verbonden aan de Erasmus School of Law van de Erasmus Universiteit Rotterdam.
De RiskMetrics Group is sinds 1 juni 2010 onderdeel van MSCI Inc.
De onderzoeksmethode inhoudsanalyse is te definiëren als systematische, objectieve en kwantita- tieve analyses van teksten om hier verdere gevolgtrekkingen uit te kunnen halen (Neuendorf, 2002). 
De Cohen's kappa (de interbeoordelaarsbetrouwbaarheid) lag tussen de 0.419 - 0.807 en is daarmee afdoende.

4 De belangrijkste beursindices zijn genomen, te weten voor het VK de FTSE100, FTSE250 en FTSESmallCap, voor België de BEL20, BELM en BELS, voor Duitsland de DAX30, MDAX en SDAX, voor Italië de S\&P/MIB en de MIBTEL, en voor Nederland de AEX, AMX en AMS.

5 De ANOVA-test heeft een significantie van 0,001 en lager en de F-waarde is tussen 5,831 en 21,707, implicerend dat deze ANOVA-test significant is (Field, 2005).

6 De metaregulering, small caps en twee-nabelangrijkkste index dummy's zijn van de twee modellen uitgesloten omdat: (i) telkens één dummy minder is benodigd voor de lineaire regressie, (ii) op basis van de bivariate resultaten worden juist deze dummy's van het model uitgesloten omdat ze minder interesant zijn, en (iii) bij het testen van de verschillende modellen toonde het huidige model met deze dummy's de meeste relevantie.
De $\mathrm{R}^{2}$ is 0,156 voor model Codenalevingl en 0,157 voor model Codenalevingll implicerend dat $16 \%$ van de totale variatie in de codenaleving is te verklaren door de onafhankelijke variabelen. De F-waarden zijn 16,257 voor Codenalevingl en 16,368 voor Codenalevingll en beide significant $(p<0,01)$, daarmee implicerend dat de mate en kwaliteit van codenaleving significant door de modellen kan worden uitgelegd en voorspeld.

\section{Literatuur}

- Arcot, S.R., \& Bruno, V.G. (2007). One size does not fit all, after all: Evidence from Corporate Governance. Geraadpleegd op http:// ssrn.com/abstract=887947.

- Arcot, S.R., \& Bruno, V.G. (2006). In letter but not in spirit: An analysis of corporate governance in the UK. Geraadpleegd op http://ssrn. com/abstract=819784.

- Boot, A.W.A., \& Soeting, R. (2004). De onderneming in een spagaat. Maandblad voor Accountancy en Bedrijfseconomie, 4(4), 178 184.

- Dalen, J. van, \& Leede, E. de. (2002). Statistisch onderzoek met SPSS. Utrecht: Lemma.

- Dedman, E. (2000). An investigation into the determinants of UK board structure before and after Cadbury. Corporate Governance: An International Review, 8(2), 133-153.

- DiMaggio, P.J., \& Powell, W.W. (1983). The iron cage revisited: Institutional isomorphism and collective rationality in organizational fields. American Sociological Review, 48, 147-160.

- Durisin, B., \& Puzone, F. (2009). Maturation of corporate governance research 1993-2007: An assessment. Corporate Governance: An International Review, 17(3), 266-291.

- Europese Commissie (2011). Green paper: The EU corporate governance framework. Geraadpleegd op http://ec.europa.eu/.

- Field, A. (2005). Discovering statistics using SPSS. Londen, Engeland: Sage Publications.

- Galle, J.G.C.M. (2012). Consensus on the 'comply or explain'-principle within the EU Corporate Governance framework: legal and empirical research. Deventer: Kluwer.

- Hooghiemstra, R., Ees, H. van, \& Laan, G. van der (2008). Non-compliance with corporate governance codes. An institutional perspective (Working Paper, Rijksuniversiteit Groningen, Groningen).

- Jensen, M.C., \& Meckling, W.H. (1976). Theory of the firm: Managerial behavior, agency costs and ownership structure. Journal of Financial Economics, 3(4), 305-360.

- Leftwich, R. (1980). Market failure fallacies and accounting information. Journal of Accounting and Economics, 2(3), 193-211.

- Maurer, J.G. (1971). Readings in organizational: Open system approaches. New York, NY: Random House.

- Monitoring Commissie Corporate Governance Code (2012). Vierde rapport over de naleving van de Nederlandse Corporate Governance Code. Geraadpleegd op http://commissiecorporategovernance.nl/.

- Neu, D., Warsame, H., \& Pedwell, K. (1998). Managing public impressions: Environmental disclosures in annual reports. Accounting, Organizations and Society, 23(3), 265-282.

- Neuendorf, K.A. (2002). The content analysis guidebook. Londen, Engeland: Thousand Oaks Sage Publications.

- Pollock, T.G., Fischer, H.M. \& Wade, J.B. (2002). The role of power and politics in the repricing of executive options. Academy of Management Journal, 45(6), 1172-1182.

- RiskMetrics Group (2009). Study on monitoring and enforcement practices in corporate governance in the member states. Geraadpleegd op http://ec.europa.eu/.

- Santen, B.P.A. (2007). De economische theorie, in A. de Bos \& W.J. Slagter: Financieelrecht vanuit economisch en juridisch perspec- tief, Deventer: Kluwer, 19-36.

- Schön, W. (2006). Corporate disclosure in a competitive environment: The ECJ's Axel Springer Case and the quest for a European framework for mandatory disclosure (ECGI Working Paper Series No. 55/2006). Geraadpleegd op http://ssrn.com/abstract=885961.

- Shabbir, A. (2008). To comply or not to comply: Evidence on changes and factors associated with the changes in compliance with the UK Code of corporate governance (Research Paper no. 5/08, Cranfield University, Bedford). Geraadpleegd op http://ssrn.com/abstract=1101412.

- Talaulicar, T., \& Werder, A. von. (2008). Patterns of compliance with the German corporate governance code. Corporate Governance: An International Review, 16(4), 255-273.

- Von Werder, A., T. Talaulicar, et al. (2005). Compliance with the German Corporate Governance Code: an empirical analysis of the compliance statements by listed companies. Corporate Governance: An International Review, 13, 178-187.

- Voogsgeerd, H.H. (2006). Corporate governance codes: Markt- of rechtsarrangement? Deventer: Kluwer.

- Weir, C., \& Laing, D. (2000). The performance-governance relationship: The effects of Cadbury compliance on UK quoted companies. Journal of Management and Governance, 4, 265-281.

- Wymeersch, E. (2005). Enforcement of corporate governance codes (ECGI Working Paper Series No. 46/2005). Geraadpleegd op http:// ssrn.com/abstract=759364. 